\title{
New Evidence on the Interest Rate Effects of Budget Deficits and Debt
}

\author{
Thomas Laubach* \\ Board of Governors of the Federal Reserve System
}

May 2003

\begin{abstract}
Estimating the effects of government debt and deficits on Treasury yields is complicated by the need to isolate the effects of fiscal policy from other influences. To abstract from the effects of the business cycle, and associated monetary policy actions, on debt, deficits, and interest rates, this paper studies the relationship between long-horizon expected government debt and deficits, measured by $\mathrm{CBO}$ and OMB projections, and expected future long-term interest rates. The estimated effects of government debt and deficits on interest rates are statistically and economically significant: a one percentage point increase in the projected deficit-to-GDP ratio is estimated to raise long-term interest rates by roughly 25 basis points. Under plausible assumptions these estimates are shown to be consistent with predictions of the neoclassical growth model.

JEL classification: E6, H6.
\end{abstract}

Keywords: Government debt, government deficits, interest rate regressions, CBO projections, OMB projections.

\footnotetext{
*tlaubach@frb.gov. I gratefully acknowledge helpful comments from numerous colleagues at the Federal Reserve Board, in particular Darrel Cohen, Douglas Elmendorf, Glenn Follette, David Reifschneider, John Roberts, and David Wilcox, as well as from Ken Matheny. Sarah Alves provided excellent research assistance. All remaining errors are mine. The views expressed herein are those of the author and do not necessarily reflect those of the Board of Governors of the Federal Reserve System or its staff.
} 


\section{Introduction}

Much controversy surrounds the quantitative effects of government debt and deficits on longterm real interest rates. Economic theory provides different answers depending on issues such as whether deficits reflect changes in government expenditures or shifts in the timing of taxes, and on the planning horizon of households who hold government debt and pay taxes. One might hope that empirical evidence could be brought to bear on this question, but here the results are just as ambiguous. One major obstacle in obtaining empirical estimates is the need to isolate the effects of fiscal policy from the many other factors affecting interest rates. The most obvious of these factors is the state of the business cycle. If automatic fiscal stabilizers raise deficits during recessions, while at the same time long-term interest rates fall due to monetary easing, deficits and interest rates may be negatively correlated even if the partial effect of deficits on interest rates - controlling for all other influences is positive.

This paper proposes to address this identification problem by focusing on the relationship between long-horizon forecasts of both interest rates and fiscal variables. Deficits and interest rates expected to prevail several years in the future are presumably little affected by the current state of the business cycle, thus greatly reducing the reverse-causality effects induced by countercyclical monetary policy and automatic fiscal stabilizers. Of course, there are many conceivable factors that jointly determine fiscal variables and interest rates, and it is unlikely that a reduced-form regression would ever completely overcome this endogeneity problem, but focusing on long-horizon forecasts is an important step in the right direction. Moreover, deficits projected several years into the future may be informative about the longer-run fiscal position, and may therefore approximate investors' expectations about the eventual level of government debt relative to GDP. Such measures of expectations thus hold out the prospect of uncovering any causal relationship from fiscal variables to interest rates.

Expectations of future fiscal policy are proxied in this paper by projections published by the Congressional Budget Office (CBO) and the Office of Management and Budget (OMB) for the federal government's unified budget deficit, the stock of federal government debt held by the public, and other fiscal variables, all expressed as percentages of the respective agency's own projection of GNP or GDP. The forecast horizon is five years in the future, which is the longest horizon for which a reasonably long time series of projections is available. Consistent with the use of 5-year-ahead projections of fiscal variables by the CBO and the 
$\mathrm{OMB}$, the analysis focuses on expectations of future nominal interest rates derived from forward rates 5 to 14 years ahead embedded in the term structure of interest rates.

The results reported below show that a percentage point increase in the projected deficitto-GDP ratio raises the 10-year bond rate expected to prevail five years into the future by 20 to 40 basis points; a typical estimate is about 25 basis points. The estimates are very precise compared to most of the literature mentioned below. Similarly, a percentage point increase in the projected debt-to-GDP ratio raises future interest rates by about 4 to 5 basis points, and these estimates are statistically significant, too. Importantly, these estimates are shown to be robust along many dimensions. Moreover, under plausible assumptions about the persistence of changes in projected deficits, the estimated 25 basis point effect on interest rates of a percentage point increase in the projected deficit-to-GDP ratio is shown to be consistent with the 4-to-5 basis point effect of an increase in the projected debt-to-GDP ratio.

This study is by no means the first to use published projections of future budget deficits. Wachtel and Young (1987) use CBO and OMB projections to analyze changes in long-term interest rates on the day of the release of the respective projection. ${ }^{1}$ Unlike those shown here, their results therefore depend on correctly identifying the unanticipated component of the release. They find that a $\$ 1$ billion increase in the projected deficit (at that time roughly 0.025 percent of nominal GDP) raises interest rates by between 0.15 and 0.4 basis points, depending on the maturity of the interest rate series and the source of the projections. Their estimates therefore imply an increase in interest rates on the order of 6 to 16 basis points in response to a percentage point increase in the deficit-to-GDP ratio. However, many of their estimates are statistically insignificant.

Cohen and Garnier (1991) and Elmendorf (1993) present results concerning the effect of deficit projections on the change in interest rates between release dates. Like the present one, these studies are based on the weaker assumption (in comparison to Wachtel and Young's) that the deficit projections are good proxies of private agent's expectations of future fiscal policy at the time of the release. The projections used in these studies, as well as in Wachtel and Young, are relatively short - for the current and next fiscal year in Wachtel and Young and in Cohen and Garnier; for up to eight quarters ahead in Elmendorf. Forecasts at this horizon are presumably still affected by the state of the business cycle. Cohen and

\footnotetext{
${ }^{1}$ Other studies using similar event analysis are Elmendorf (1996) and Kitchen (1996).
} 
Garnier address this problem by using projections for the cyclically adjusted federal deficit, thus in principle eliminating the business cycle effects. Using OMB projections, they find statistically significant effects of a percentage point increase in the projected deficit-to-GDP ratio on interest rates on the order of 40 to 55 basis points. Using DRI forecasts, Elmendorf finds a statistically significant increase in interest rates at maturities up to five years of about 50 basis points, but the effects on long-term interest rates are smaller and statistically insignificant. Canzoneri, Cumby, and Diba (2002) use 5-year-ahead and 10-year-ahead CBO projections of cumulative budget deficits and study their effects on the spread between 5year or 10-year, and 3-month Treasury yields. Their estimates are of similar magnitude as those reported in Cohen and Garnier and in Elmendorf, but are considerably more precise.

The present study confirms the importance of using measures of long-horizon expectations of deficits and debt for identifying their effects on interest rates. ${ }^{2}$ It departs from the previous studies in several respects. Unlike Canzoneri et al., this study uses the level of interest rates expected to prevail 5 years ahead instead of the slope of the term structure. As shown below, omitting the near-term component from the long-term interest rate measures further helps to identify the effects of the fiscal variables. In comparison to previous studies, I also include additional variables suggested by economic theory in the regressions; doing so again helps to identify more precisely the effects of fiscal variables on interest rates. Moreover, I present results concerning the effects of both government deficits and government debt on interest rates. Feldstein (1986) argues that the interest rate effects of deficits depend on how persistent these deficits are assumed to be. The relative magnitudes of the estimated effects of deficits and the estimated effects of debt reported below are consistent with the assumption that increases in projected deficits are persistent, but not permanent. Finally, the fourth section discusses the predictions of the neoclassical growth model - the simplest general equilibrium framework for this purpose - for the relationship between the stock of debt and interest rates. Under plausible assumptions, the empirical results are consistent with the predictions from this model.

\footnotetext{
${ }^{2}$ This point is convincingly illustrated in Elmendorf (1993). He examines the findings of studies that proxy for expectations of fiscal variables by using forecasts from VARs (see Plosser 1982, 1987, and Evans 1987). Elmendorf shows that these VAR forecasts are poor compared to projections available at the time, and that the conclusions of these studies are overturned once better measures of expectations are used. For a taxonomy of studies in this area according to their measurement of expectations see Gale and Orzsag (2002).
} 


\section{Specification and Data}

The empirical method used in this paper is to regress expected future interest rates on projections published by the CBO and the OMB for the deficit-to-GDP ratio and the debtto-GDP ratio five years ahead, as well as other determinants of long-term interest rates suggested by economic theory. As regards the latter, the Ramsey model of optimal growth, combined with a representative household with CES utility, implies that the net real return on capital, i.e. the real interest rate, is determined by

$$
r=\sigma g+\theta
$$

where $g$ denotes the net growth rate of technology, output, and consumption, $\sigma$ is the coefficient of relative risk aversion, and $\theta$ is the household's rate of time preference. This relationship therefore suggests that both trend growth and risk aversion should play a role in determining yields on risk-free Treasury instruments: an increase in trend growth should raise interest rates, whereas an increase in risk aversion should lower Treasury yields because it raises the demand for safe assets. The regressions reported in the next section are therefore variants of

$$
r_{t}=\beta_{0}+\beta_{1} f_{t}+\beta_{2} g_{t}+\beta_{3} e_{t}+\epsilon_{t}
$$

where $r_{t}$ is the real Treasury yield expected to prevail at some horizon, $f_{t}$ is a fiscal variable, e.g. the projected deficit-to-GDP ratio, $g_{t}$ is a measure of potential GDP growth, and $e_{t}$ is a measure of the equity premium discussed below.

The following discussion of the data used in this study is deliberately kept short; more details can be found in the appendix. From the CBO, five-year-ahead projections for both the unified budget deficit and GDP (GNP until 1991) are available at an annual frequency from 1976 to 1984, and at a semiannual frequency from 1985 until the most recent projection in January 2003. For the early years, the CBO did not publish projections for federal debt held by the public; those projections are therefore computed by adding the CBO's deficit projections for the current and next five fiscal years to the stock of debt held by the public at the end of the previous fiscal year. From the OMB, five-year-ahead projections of deficits, debt held by the public, and GNP or GDP are available at an annual frequency from 1983 on. I also collect projections for the net interest component of outlays, and for total outlays, which I will use later on. ${ }^{3}$

\footnotetext{
${ }^{3}$ The 5 -year-ahead projections of debt held by the public are of course affected by projected near-term
} 
Figures 1 and 2 show the actual deficit-to-GDP ratios and debt-to-GDP ratios, expressed as percent of GDP, together with CBO's and OMB's five-year-ahead projections. The projections are shown for the (fiscal) year for which they were made. Clearly, both agencies made large forecast errors, but this is irrelevant for our purpose. The only relevant question is whether these agencies' projections accurately reflect market expectations at the time the projections were made. While it is impossible to assess that issue directly, arguably these agencies' projections are using most of the information about future deficits and debt available at the time, although in different ways: Whereas the CBO's projections are usually based on fiscal policies that have been enacted at the time the projection is made, the OMB's projections include the administration's policy proposals. If market participants believe that the administration's policies are likely to pass as proposed, their expectations may be closer to the OMB's projections; in other instances, they may be closer to the CBO's. It is worth noting that over the sample for which both agencies' 5-year-ahead projections can be evaluated (fiscal years 1988 to 2002), the biases of the CBO projections (1.2 percent for the deficit/GDP ratio, 5.1 percent for the debt/GDP ratio) are larger in absolute value than those of the OMB projections (-0.7 percent and -1 percent respectively), but the standard deviations of the CBO's forecast errors (2.9 percent and 10.4 percent) are slightly smaller than those of the OMB (3.1 percent and 12 percent). There is no obvious reason why investors should prefer one agency's projections over the other, and below I will present results using both sets of projections.

For the regressions involving $\mathrm{CBO}$ projections, the interest rate data are sampled on the last trading day of the month of the CBO release. For the regressions involving OMB projections, I use the value of interest rates as recorded on the last trading day of February, except in those years in which a new administration took office, when I use observations from the last trading day of March. Three different interest rate series are considered below: the yield expected to prevail five years ahead on a 10-year Treasury note, the yield expected to prevail five years ahead on a 5-year Treasury note, and the (conventional) 10-year constant maturity Treasury yield. ${ }^{4}$ The first two are measured as simple averages of one-year forward cyclical deficits; however, the effects of the deficit in any one given year on the stock of debt is generally small.

${ }^{4}$ Although this study focuses on government yields, it should be noted that the results are likely to carry over to corporate yields. Based on regression analysis, I find no evidence that yield spreads between corporate bonds and Treasuries, adjusted for cyclical variation, are systematically related to projected deficit-to-GDP 
rates 5 to 9 years and 5 to 14 years ahead, respectively, calculated from the zero-coupon yield curve. ${ }^{5}$ Nominal interest rates are converted into real interest rates using a proxy for 10-year consumer price inflation expectations that is based on survey data for most of the sample; details are provided in the appendix. In some regressions the dependent variable is the real interest rate, whereas in others it is the nominal interest rate; in these latter regressions, inflation expectations are allowed to enter with a coefficient different from 1. The series of nominal interest rates and expected inflation, sampled in the months of annual CBO releases, are shown in figure 3.

For trend growth, I use CBO's 5-year-ahead projections of the growth rate of real GNP or GDP as a proxy for agents' views about the trend growth rate of the economy at a given point in time. It is also the growth rate that is consistent with CBO's deficit projections five years ahead. The equity premium, used as a proxy for risk aversion, is calculated as the dividend component of national income, expressed as percent of the market value of corporate equity held (directly or indirectly) by households, minus the real 10-year Treasury yield, plus the trend growth rate. I use the value of the equity premium in the quarter prior to the release of the respective budget projections, assuming that this is the best available forecast of this variable five years ahead. Because the equity premium is a function of the real 10-year Treasury yield, the issue of simultaneity of the dependent variable and this measure of the equity premium is addressed below. Both series are shown in figure 4 .

\section{Empirical Results}

Table 1 presents some baseline results, using the real 5-year-ahead 10-year Treasury yield as the dependent variable. It reports the estimated coefficients on the deficit-to-GDP and debt-to-GDP ratios, both expressed as percentages of GDP, trend growth, and the equity premium; the intercept estimate is omitted from all tables. Also shown are the $R^{2}$, the standard error of the regression, the Durbin-Watson statistic, and the number of observaratios.

${ }^{5}$ It has often been noted that forward rates are biased predictors of future interest rates, presumably because they include term and/or risk premia. For the 5-year-ahead 10-year interest rate used here, for example, the bias throughout the 1990s is about 2 percent. Because forward rates are affecting current interest rates and hence the current cost of capital relevant for business and residential investment, however, the fact that forward rates may not be unbiased predictors of future interest rates is not a concern. 
tions. The $t$ statistics are based on standard errors using the Newey-West correction for heteroskedasticity and serial correlation; the lag truncation, based on automatic selection criteria, is 3 for the CBO data, and 2 for the OMB data. ${ }^{6}$

The first two columns show the results for the largest data set, the CBO projections including the mid-year updates from 1985 on. The coefficient on the deficit-to-GDP ratio is 0.29 and its $t$ statistic is large. The coefficient on the debt-to-GDP ratio is also highly significant, and as argued below, its size appears to be consistent with the estimated coefficient on the deficit-to-GDP ratio. Trend growth and the equity premium enter with statistically significant and economically meaningful coefficients. The Durbin-Watson statistics indicate some degree of serial correlation in the residuals of both regressions. As shown in columns 3 and 4 , omitting the mid-year updates eliminates this problem without significantly affecting the other results; in the following I will only use the annual CBO data. Columns 5 and 6 show that similar results are obtained using OMB's projections, except that the coefficients on the fiscal variables are no longer estimated as precisely as for the CBO projections.

To provide some idea of the interest rate effects predicted by these regressions, consider the CBO's annual projections. Between January 2001 and January 2003, the CBO's 5year-ahead projection of the surplus-to-GDP ratio declined from 3.8 percent to about 0.5 percent. The regression shown in column 3 implies that this swing raised the 5 -year-ahead real interest rate by 92 basis points, everything else equal. Similarly, the projected 5 -yearahead debt-to-GDP ratio increased from about 9.5 percent to 28.5 percent; the regression shown in column 4 implies that, all else equal, this swing raised the 5 -year-ahead real interest rate by 99 basis points.

Tables 2 and 3 examine the robustness of these results along several dimensions. The dependent variable in these tables continues to be the 5-year-ahead 10-year Treasury yield. Despite the use of long-horizon projections, it is possible that the results may not only reflect the effects of fiscal policy on interest rates, but may also confound those effects with monetary policy. The early 1980s in particular are an episode in which both projected deficits and interest rates rose sharply, with the latter arguably driven at least in part by the Volcker disinflation. The first two columns of table 2 therefore present the same regressions shown in table 1, using annual CBO projections only from 1985 on - that is,

\footnotetext{
${ }^{6} \mathrm{~A}$ caveat in interpreting the $t$ statistics is that augmented Dickey-Fuller tests do not reject the hypothesis of a unit root at the 5 percent level for either the dependent variable or for the regressors. In view of the small number of observations, however, these tests have very low power.
} 
after the most intense phase of the disinflation had been completed. ${ }^{7}$ As shown in column 1 , the coefficient on the deficit-to-GDP ratio is slightly larger, and its $t$ statistic very high. The results shown in column 2 using the debt-to-GDP ratio are nearly identical to those for the full sample.

A different approach to assessing the role of the early 1980s is to use nominal yields as the dependent variable, and to include expected inflation as an additional regressor. As shown in columns 3 to 6 , the coefficient on expected inflation is always estimated to be larger than 1. This finding may reflect a demand by investors for increased risk premia on nominal assets to compensate for greater uncertainty about future inflation when the current level of inflation is elevated (see e.g. Okun (1971) and Ball and Cecchetti (1990)). In addition, Feldstein (1976) points out that, because taxes are levied on nominal returns, nominal interest rates have to increase more than one-for-one with expected inflation. Consequently, in these regressions the implied effect of the rising deficits of the early 1980s on real interest rates is attenuated. This is because, relative to the earlier regressions in which nominal yields and expected inflation move one for one by assumption, a larger portion of the high level of nominal interest rates during this period is now attributed to high expected inflation. Consistent with this reasoning, the estimated coefficients on the fiscal variables are slightly smaller than those presented in table 1, but still highly significant. Returning to the example above, the results shown in columns 3 and 4 imply that the revisions to the CBO's projections between January 2001 and January 2003 added about 75 basis points to 5 -year-ahead long-term interest rates, all else equal. The improvement in the regression $R^{2}$ is almost entirely due to the change in the dependent variable, as shown by the nearly unchanged regression standard errors. Because of the economic arguments mentioned before, however, the following tables report results for regressions with nominal yields as dependent variables.

Two issues related to including trend growth and the equity premium in the regressions are addressed in table 3. The first is how omitting one or both of these variables affects the estimated coefficients on the fiscal variables. To be concise, results are shown only for annual CBO data. The first two columns show results when both variables are omitted from the regression, and the next two columns show results when only the equity premium

\footnotetext{
${ }^{7}$ Results using OMB projections from 1985 on are little changed from those shown in table 1, as only the first two observations are omitted.
} 
is omitted. Comparing those results to the ones shown in the middle two columns of table 2 , we find that the coefficients on both fiscal variables are quite similar whether one or both of the non-fiscal regressors are omitted. However, the coefficients on growth are essentially zero when the equity premium is omitted. For the theoretical reasons discussed in the previous section, I will continue to include both variables in the regressions. ${ }^{8}$

A different concern is that the equity premium contains the real 10-year Treasury yield, and is therefore correlated with the residual. In the last two columns of table 3 I report results from regressions in which I use the lagged equity premium as instrument for the current equity premium. Compared to the results shown in the middle two columns of table 2 , the only notable difference is that the $t$ statistics on the equity premium fall to 1.7 . The results concerning the fiscal variables, however, are robust.

Table 4 assesses the effects of using either the current 10-year Treasury yield, or the 5-year Treasury yield expected to prevail five years ahead, instead of the 10-year Treasury yield expected to prevail five years ahead. For convenience, the last two columns repeat the results shown in the middle two columns of table 2. The results using the conventional 10-year Treasury yield show clearly that controlling for the cyclical variation embedded in the short end of the yield curve is important for identifying the effects of fiscal variables on interest rates. ${ }^{9}$ Once the first five years of the term structure are omitted, the point estimates using the 5-year-ahead 5-year yield are similar to those using the 5-year-ahead 10 -year yield, but not as precise. ${ }^{10}$

Finally, table 5 considers the effects of using two other combinations of fiscal variables. The first column in table 5 addresses the concern of reverse causation from the interest rate to projected deficits through higher outlays on debt service. Here the regressor is the ratio of the primary deficit, defined as the projected deficit less projected net interest outlays, to projected GDP. The coefficient on the primary deficit is larger than the coefficient on the deficit shown in table 2 , and its $t$ statistic about the same. The second column shows

\footnotetext{
${ }^{8}$ Qualitatively the same results obtain when using OMB projections, except that the coefficient on the debt-to-GDP ratio in the regression including growth remains significant at the $5 \%$ level, with a $t$ statistic of 2.28. It should also be noted that the coefficient on trend growth remains significant in the regressions shown in tables 3 through 5 when the dependent variable is the real 5-year-ahead Treasury yield.

${ }^{9}$ When using the real 10-year yield as dependent variable, however, the coefficients on the fiscal variables remain significant and of similar magnitude as those reported in the middle two columns of table 1 , although their $t$ statistics are lower than those reported there.

${ }^{10}$ Again, the same conclusions obtain using OMB projections.
} 
the results from including the projections for the primary deficit and total outlays, both expressed as percentage of GDP, in the regressions. The question is whether the effects of deficits on interest rates depend on whether the deficits are caused by spending increases or by changes in the timing of taxes. According to Ricardian equivalence, for example, changes in projected deficits without changes in government purchases should leave expected interest rates unchanged. If so, the coefficient on the projected deficit-to-GDP ratio in a regression including projected government purchases should be zero. By contrast, the coefficient on the deficit-to-GDP ratio shown in the second column is even higher than before, whereas that on projected total outlays is negative, but statistically insignificant. The sum of the coefficients on the two fiscal variables in column 2 is close to the coefficient on the projected deficit-to-GDP ratio in column 1 , and its $t$ statistic is 2.67 . The counterintuitive sign on total outlays may in part reflect the fact that total outlays include transfer payments as well as government purchases. ${ }^{11}$

Is the result that the estimated coefficients on the deficit-to-GDP ratio are about seven times as large as the ones on the debt-to-GDP ratio economically plausible? If increases in deficits were serially uncorrelated, so that the effect of a projected increase in the deficit on the stock of debt in subsequent years would be simply one for one, the coefficients on the deficit-to-GDP ratio and the debt-to-GDP ratio ought to be the same. But consider the opposite extreme, in which every increase in projected deficits is expected to be permanent. The steady-state effect on the debt-to-GDP ratio of a permanent one percentage point increase in the deficit-to-GDP ratio is $(1+g) / g$ percent, where $g$ is the net growth rate of nominal GDP. Over the sample 1976-2003, this growth rate averaged about 8 percent per year, implying that the coefficient on the deficit-to-GDP ratio ought to be 13.5 times as large as the coefficient on the debt-to-GDP ratio. The fact that the estimated coefficients on the deficit-to-GDP ratio are about seven times as large as those on the debt-to-GDP ratio is consistent with the view that investors perceive increases in projected deficit-to-GDP ratios as highly persistent (as they are in the historical data), but not strictly permanent.

\footnotetext{
${ }^{11}$ The results shown in table 5 are nearly unaffected when using instead the real five-year-ahead 10-year yield as dependent variable.
} 


\section{Are the Results Consistent with Economic Theory?}

A skeptical view of the evidence presented in the previous section would hold that the identification problems involved in these kinds of regressions are too severe to be ever completely overcome. One may therefore ask whether the empirical results can be reconciled with priors based on economic theory. One potential answer to this question, based on the neoclassical growth model, is sketched below; the argument is closely akin to the one developed in Elmendorf and Mankiw (1999). ${ }^{12}$ Because in the neoclassical growth model the real interest rate is determined by the capital-output ratio, the discussion below focuses on the link between the stock of debt and the capital stock, and assesses the plausibility of the results for the debt-to-GDP ratio reported in the previous section. As Elmendorf and Mankiw (1999) point out, however, whether it is deficits or debt that matter for the determination of interest rates depends ultimately on which model of consumer behavior one assumes. The analysis below therefore illustrates only one particular argument by which the empirical results can be related to economic theory.

Suppose that an increase in government debt reduces the private capital stock by a fraction $c$; that is, if $D$ denotes the stock of government debt, and $K$ the private capital stock, $\partial K / \partial D=-c$. The parameter $c$ denotes the degree of crowding out, with the remaining fraction $1-c$ being the increase in private savings or capital inflows from abroad in response to the increase in the interest rate. Assuming factors of production earn their marginal product, the share of capital in income, $s$, is equal to the marginal product of capital times the capital-output ratio $k=K / Y$. Moreover, the marginal product is equal to the sum of the depreciation rate $d$ of the private capital stock and the real interest rate $r$. Hence we can solve for $r$ as $r=s / k-d$.

The effect of a one percentage point increase in the debt-to-GDP ratio on $r$ can now be computed by calculating the partial derivative $\partial r / \partial D=\partial r / \partial k \cdot \partial k / \partial K \cdot(-c)$. Using a Cobb-Douglas production function $Y=K^{s} L^{1-s}$, we find that $k=K^{1-s} L^{-(1-s)}$, and therefore $\partial k / \partial K=(1-s) / Y$. Putting the pieces together, an increase $\Delta D=0.01 Y$ raises the interest rate by $(1-s) c s / k^{2}$ basis points.

The final step in obtaining numerical predictions of the interest rate effects is to choose values for $c, s$, and $k$. As an example, consider $s=0.33$, consistent with a capital share

\footnotetext{
${ }^{12}$ A similar argument is used in Council of Economic Advisers (2003).
} 
in national income accounts data of about $1 / 3$. For the parameter $k$, consider the BEA's estimate of private fixed assets at the end of 2001 ( $\$ 22.2$ trillion) divided by output in the nonfarm business sector in 2002 (approximately $\$ 8.4$ trillion). This yields $k=2.5$. The most difficult parameter to quantify is the degree of crowding out, $c$. Elmendorf and Mankiw (1999) survey a number of studies which show that, under assumptions for households' intertemporal elasticity of substitution consistent with household data, the increase in private savings in response to the change in interest rates is close to zero. Moreover, recent studies in the vein of Feldstein and Horioka (1980) suggest that roughly two-thirds of saving in developed countries is retained for domestic investment in the long run, implying that capital inflows from abroad offset about one-third of the increase in debt. Suppose, therefore, that $c=0.6$. Then a one percentage point increase in the debt-to-GDP ratio raises the real interest rate by 2.1 basis points. This is only half of the effect reported in the regressions using the real interest rate as dependent variable, but only slightly less than the estimates reported in Tables 2 and 3 using the nominal interest rate as the dependent variable.

It should be noted, however, that the estimate of 2.1 basis points is conservative because it takes into consideration the endogenous response of output to the decline in the capital stock, but it omits the second-round effect that the debt-to-GDP ratio is effectively increasing by more than one percentage point. Moreover, as pointed out in the previous section, increases in projected deficits tend to be highly persistent, and hence a given increase in the 5-year-ahead projected debt-to-GDP ratio might be expected to be followed by larger increases in the debt-to-GDP ratio beyond five years into the future. If so, a percentage point increase in the debt-to-GDP ratio projected five years ahead should be associated with an increase in interest rates larger than the one implied by a percentage point increase in the steady state debt-to-GDP ratio predicted by the model.

\section{Conclusions}

This study has shown that statistically significant and economically plausible estimates of the effects of government deficits and debt on interest rates can be obtained by focusing on long-horizon forecasts of future deficits or debt, and future interest rates. The projections of deficits and debt published by the $\mathrm{CBO}$ and the OMB are arguably among the best publicly 
available forecasts for these variables. The effects of these projections manifest themselves at the longer end of the yield curve, as economic reasoning would predict. All else equal, the results of this study suggest that interest rates rise by about 25 basis points in response to a percentage point increase in the projected deficit-to-GDP ratio, and by about 4 basis points in response to a percentage point increase in the projected debt-to-GDP ratio.

\section{References}

[1] Ball, Laurence, and Stephen G. Cecchetti. "Inflation and Uncertainty at Long and Short Horizons." Brookings Papers on Economic Activity 1:1990, 215-245.

[2] Canzoneri, Matthew B., Robert E. Cumby, and Behzad Diba. "Should the European Central Bank and the Federal Reserve be Concerned About Fiscal Policy?" In Rethinking Stabilization Policy, Federal Reserve Bank of Kansas City 2002.

[3] Cohen, Darrel, and Olivier Garnier. "The Impact of Forecasts of Budget Deficits on Interest Rates in the United States and other G-7 Countries." Federal Reserve Board, 1991.

[4] Council of Economic Advisers. Economic Report of the President. Washington, D.C., February 2003.

[5] Elmendorf, Douglas W. "Actual Budget Deficit Expectations and Interest Rates." Harvard Institute of Economic Research, May 1993.

[6] Elmendorf, Douglas W. "The Effects of Deficit Reduction Laws on Real Interest Rates." Federal Reserve Board, Finance and Economics Discussion Series 1996-44.

[7] Elmendorf, Douglas W., and N. Gregory Mankiw. "Government Debt." Chapter 25 in John B. Taylor and Michael Woodford (eds.), Handbook of Macroeconomics, Vol. 1, Amsterdam: Elsevier Science 1999.

[8] Evans, Paul. "Interest Rates and Expected Future Budget Deficits in the United States." Journal of Political Economy 95 (1987), 34-58.

[9] Feldstein, Martin S. "Inflation, Income Taxes, and the Rate of Interest: A Theoretical Analysis." American Economic Review 66 (1976), 809-820. 
[10] Feldstein, Martin S. "Budget Deficits, Tax Rules, and Real Interest Rates." NBER Working Paper No. 1970, July 1986.

[11] Feldstein, Martin S., and Charles Horioka. "Domestic Savings and International Capital Flows." Economic Journal 90 (1980), 314-329.

[12] Gale, William G., and Peter R. Orszag. "The Economic Effects of Long-Term Fiscal Discipline." Tax Policy Center, Urban Institute and Brookings Institution, December 2002.

[13] Kitchen, John. "Domestic and International Financial Market Responses to Federal Deficit Announcements." Journal of International Money and Finance 15 (1996), 239254.

[14] Kozicki, Sharon, and Peter A. Tinsley. "Shifting Endpoints in the Term Structure of Interest Rates." Journal of Monetary Economics 47 (2001), 613-652.

[15] Okun, Arthur. "The Mirage of Steady Inflation." Brookings Papers on Economic Activity 2:1971, 485-498.

[16] Plosser, Charles I. "Government Financing Decisions and Asset Returns." Journal of Monetary Economics 9 (1982), 325-352.

[17] Plosser, Charles I. "Fiscal Policy and the Term Structure." Journal of Monetary Economics 20 (1987), 343-367.

[18] Wachtel, Paul, and John Young. "Deficit Announcements and Interest Rates." American Economic Review 77 (1987), 1007-1012.

\section{A The Data}

The OMB data are taken from the annual releases of the administration's budget published in February, or slightly later in years in which a new administration took office. The months of CBO releases used in this study (releases omitted from the annual data set are marked by *) are 1/76, 12/76, 1/78, 1/79, 2/80, 7/81, 2/82, 2/83, 2/84, 2/85, 8/85* , 2/86, 8/86* , 1/87, $8 / 87^{*}, 2 / 88,8 / 88^{*}, 1 / 89,8 / 89^{*}, 1 / 90,7 / 90^{*}, 1 / 91,8 / 91^{*}, 1 / 92,8 / 92^{*}, 1 / 93,9 / 93^{*}, 1 / 94$, 8/94*, 1/95, 8/95* 12/95*, 5/96, 1/97, 9/97* 1/98, 8/98* 1/99, 7/99*, 1/00, 7/00* , 1/01, 
$8 / 01^{*}, 1 / 02,8 / 02^{*}, 1 / 03$. For the early years of the sample (1976-1982), constructing the series of both projected deficits and debt entails a choice because the CBO reported different projections of future deficits depending mainly on alternative assumptions regarding policy responses to the inflation-induced uptrend in tax receipts. To be consistent across the entire sample, I used the estimates based on the assumption of no policy change. The January 1991 projections are not the CBO baseline, but are based on the already legislated discretionary spending caps, which were the CBO's baseline for the remainder of the 1990s. The December 1995 projections are included despite the fact that they were based on a budget resolution already vetoed by the President. By contrast, the August 1996 update is omitted because of incomplete projections, given that the annual projections had only been published in May.

The series of inflation expectations, which is taken from the Federal Reserve Board's FRB/US model, consists of three different pieces. Until 1981:Q1, the series is an estimated step function based on the changepoint model developed in Kozicki and Tinsley (2001). From 1981:Q2 until 1991:Q2, the series is based on the Hoey survey of decision makers, which was conducted by Drexel-Burnham-Lambert, and later by Barclays De Zoete Wedd. Participants in this survey were polled for their expectation of CPI inflation ten years ahead. Finally, since 1991:Q3 the series is based on the Survey of Professional Forecasters conducted by the Federal Reserve Bank of Philadelphia, in which participants are asked for their expectation of CPI inflation over the next ten years. Thus, while the series is not ideal for our purposes, it should provide a good measure of inflation expectations over either of the horizons of the nominal yield series described above. The series is extrapolated to monthly frequency, and is sampled in the months corresponding to the yield data. 
Table 1: Results for Real 5-Year-Ahead 10-Year Treasury Yield

\begin{tabular}{|c|cc|cc|cc|}
\hline & \multicolumn{7}{|c|}{ Source of Projections } \\
& CBO, Semiann. & CBO, Annual & \multicolumn{2}{c|}{ OMB } \\
\hline Proj. Deficit/GDP & .29 & - & .28 & - & .40 & - \\
& $(10.83)$ & & $(12.07)$ & & $(4.45)$ & \\
Proj. Debt/GDP & - & .053 & - & .052 & - & .053 \\
& & $(5.52)$ & & $(5.22)$ & & $(3.32)$ \\
Trend Growth & 1.11 & 1.53 & 1.02 & 1.45 & 1.01 & 1.51 \\
& $(4.10)$ & $(3.70)$ & $(3.39)$ & $(3.10)$ & $(2.69)$ & $(2.77)$ \\
Eq. Premium & -.41 & -.45 & -.41 & -.48 & -.40 & -.36 \\
& $(4.83)$ & $(3.69)$ & $(4.32)$ & $(3.88)$ & $(2.29)$ & $(2.05)$ \\
\hline$R^{2}$ & .61 & .44 & .65 & .48 & .58 & .49 \\
S.E. & .64 & .76 & .70 & .85 & .64 & .70 \\
DW & 1.14 & .97 & 2.06 & 2.07 & 2.20 & 2.16 \\
$N$ & 46 & 46 & 28 & 28 & 21 & 21 \\
\hline & \multicolumn{7}{|c|}{} \\
\hline Notes: Newey-West $t$ statistics in parentheses.
\end{tabular}


Table 2: Results for Shorter Sample and for Nominal Yields

\begin{tabular}{|c|c|c|c|c|c|c|}
\hline & \multicolumn{2}{|c|}{ CBO, 1985-2003 } & \multicolumn{2}{|c|}{ CBO, Nom. Yield } & \multicolumn{2}{|c|}{ OMB, Nom. Yield } \\
\hline Exp. Inflation & - & - & $\begin{array}{c}1.19 \\
(5.63)\end{array}$ & $\begin{array}{c}1.32 \\
(5.96)\end{array}$ & $\begin{array}{c}1.12 \\
(10.88)\end{array}$ & $\begin{array}{c}1.16 \\
(10.37)\end{array}$ \\
\hline Proj. Deficit/GDP & $\begin{array}{c}.30 \\
(6.36)\end{array}$ & - & $\begin{array}{c}.23 \\
(4.17)\end{array}$ & - & $\begin{array}{c}.36 \\
(3.29)\end{array}$ & - \\
\hline Proj. Debt/GDP & - & $\begin{array}{c}.053 \\
(5.05)\end{array}$ & - & $\begin{array}{c}.036 \\
(2.46)\end{array}$ & - & $\begin{array}{c}.046 \\
(2.68)\end{array}$ \\
\hline Trend Growth & $\begin{array}{c}1.11 \\
(3.43)\end{array}$ & $\begin{array}{c}1.58 \\
(3.12)\end{array}$ & $\begin{array}{c}.68 \\
(1.53)\end{array}$ & $\begin{array}{c}.72 \\
(1.06)\end{array}$ & $\begin{array}{c}.86 \\
(2.28)\end{array}$ & $\begin{array}{c}1.26 \\
(2.28)\end{array}$ \\
\hline Eq. Premium & $\begin{array}{c}-.37 \\
(3.58) \\
\end{array}$ & $\begin{array}{c}-.41 \\
(2.98) \\
\end{array}$ & $\begin{array}{c}-.40 \\
(4.30) \\
\end{array}$ & $\begin{array}{c}-.45 \\
(3.33) \\
\end{array}$ & $\begin{array}{c}-.41 \\
(2.41) \\
\end{array}$ & $\begin{array}{c}-.37 \\
(2.19) \\
\end{array}$ \\
\hline$R^{2}$ & .68 & .58 & .92 & .90 & .91 & .90 \\
\hline S.E. & .56 & .64 & .69 & .79 & .64 & .70 \\
\hline DW & 1.86 & 2.16 & 2.05 & 2.04 & 2.38 & 2.33 \\
\hline$N$ & 19 & 19 & 28 & 28 & 21 & 21 \\
\hline
\end{tabular}

Table 3: The Role of Trend Growth and the Equity Premium

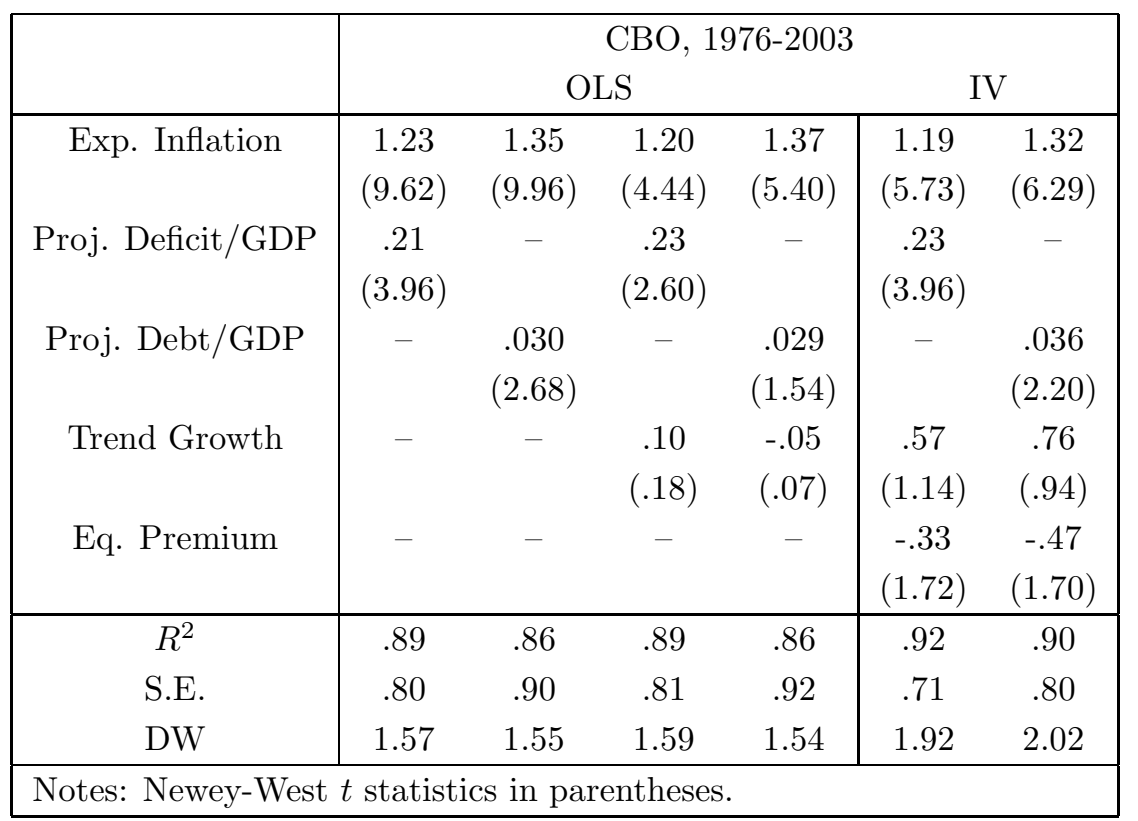


Table 4: The Role of Forward Rates and Maturities

\begin{tabular}{|c|c|c|c|c|c|c|}
\hline & \multicolumn{6}{|c|}{$\mathrm{CBO}, 1976-2003$} \\
\hline & \multicolumn{2}{|c|}{ 10-Year Yield } & \multicolumn{2}{|c|}{ 5-Y-Ah-5-Y Yield } & \multicolumn{2}{|c|}{ 5-Y-Ah-10-Y Yield } \\
\hline & 1.62 & 1.71 & 1.21 & 1.31 & 1.19 & 1.32 \\
\hline Exp. Inflation & $(7.13)$ & $(7.85)$ & $(5.94)$ & $(6.71)$ & $(5.63)$ & $(5.96)$ \\
\hline \multirow[t]{2}{*}{ Proj. Deficit/GDP } & .09 & - & .19 & - & .23 & - \\
\hline & $(1.40)$ & & $(2.38)$ & & $(4.17)$ & \\
\hline \multirow[t]{2}{*}{ Proj. Debt/GDP } & - & .007 & - & .033 & - & .036 \\
\hline & & $(.45)$ & & $(2.14)$ & & $(2.46)$ \\
\hline \multirow[t]{2}{*}{ Trend Growth } & .73 & .59 & .65 & .76 & .68 & .72 \\
\hline & $(1.25)$ & $(.80)$ & $(1.40)$ & $(1.23)$ & $(1.53)$ & $(1.06)$ \\
\hline \multirow[t]{2}{*}{ Eq. Premium } & -.72 & -.72 & -.50 & -.54 & -.40 & -.45 \\
\hline & $(4.93)$ & $(4.13)$ & $(3.66)$ & $(3.31)$ & $(4.30)$ & $(3.33)$ \\
\hline$R^{2}$ & .93 & .93 & .90 & .89 & .92 & .90 \\
\hline S.E. & .76 & .79 & .79 & .84 & .69 & .79 \\
\hline DW & 1.47 & 1.53 & 1.50 & 1.62 & 2.05 & 2.04 \\
\hline
\end{tabular}

Table 5: Other Combinations of Fiscal Variables

\begin{tabular}{|c|c|c|}
\hline & \multicolumn{2}{|c|}{$\mathrm{CBO}, 1976-2003$} \\
\hline & $\begin{array}{c}\text { Primary } \\
\text { Deficit }\end{array}$ & $\begin{array}{l}\text { Pr. Deficit } \\
\text { and Outlays }\end{array}$ \\
\hline Exp. Inflation & $\begin{array}{c}1.22 \\
(6.63)\end{array}$ & $\begin{array}{c}1.28 \\
(6.04)\end{array}$ \\
\hline Proj. Deficit/GDP & $\begin{array}{c}.32 \\
(4.35)\end{array}$ & $\begin{array}{c}.41 \\
(4.75)\end{array}$ \\
\hline Outlays/GDP & - & $\begin{array}{l}-.13 \\
(.97)\end{array}$ \\
\hline Trend Growth & $\begin{array}{c}.58 \\
(1.46)\end{array}$ & $\begin{array}{c}.48 \\
(1.09)\end{array}$ \\
\hline Eq. Premium & $\begin{array}{c}-.41 \\
(4.16)\end{array}$ & $\begin{array}{c}-.41 \\
(3.79)\end{array}$ \\
\hline$R^{2}$ & .93 & .93 \\
\hline S.E. & .68 & .68 \\
\hline DW & 2.00 & 2.13 \\
\hline
\end{tabular}


Figure 1: Actual and Projected Deficits as Percent of GDP

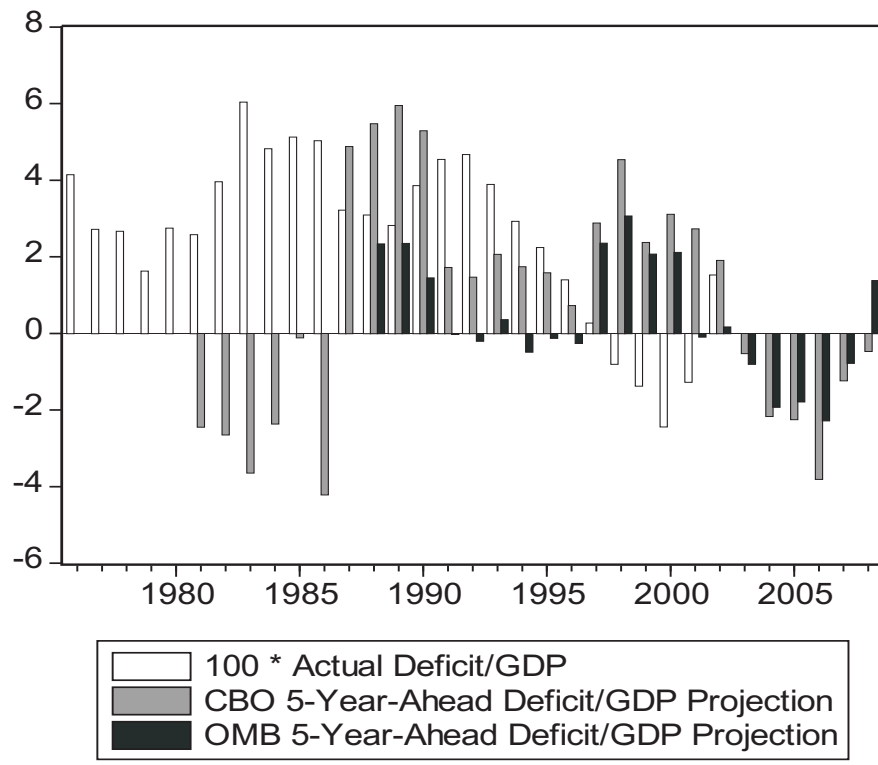

Figure 2: Actual and Projected Debt as Percent of GDP
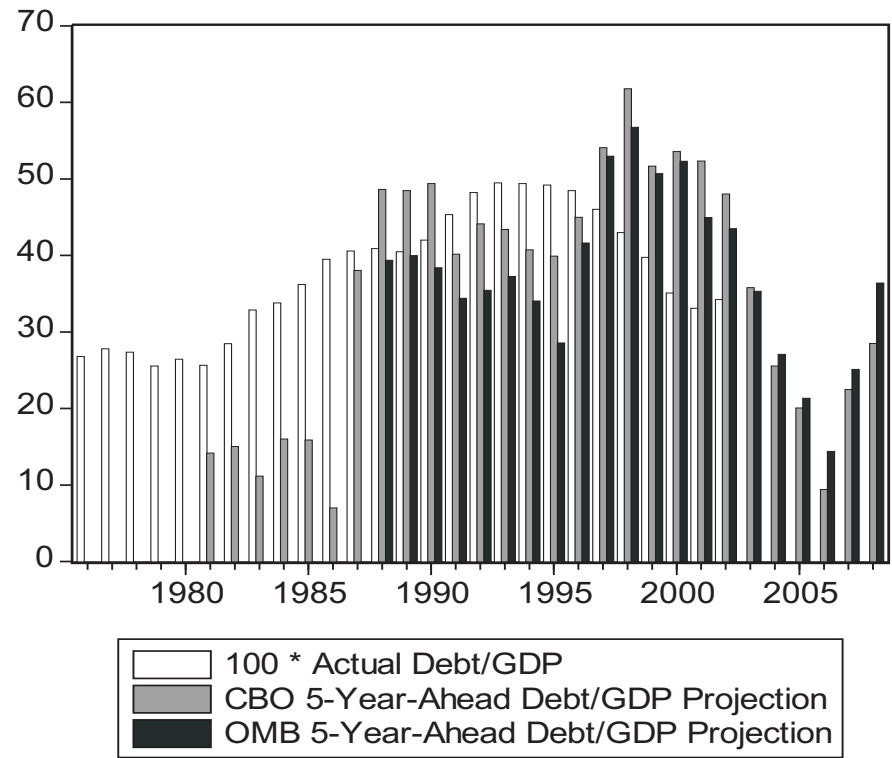
Figure 3: Interest Rates and Inflation Expectations

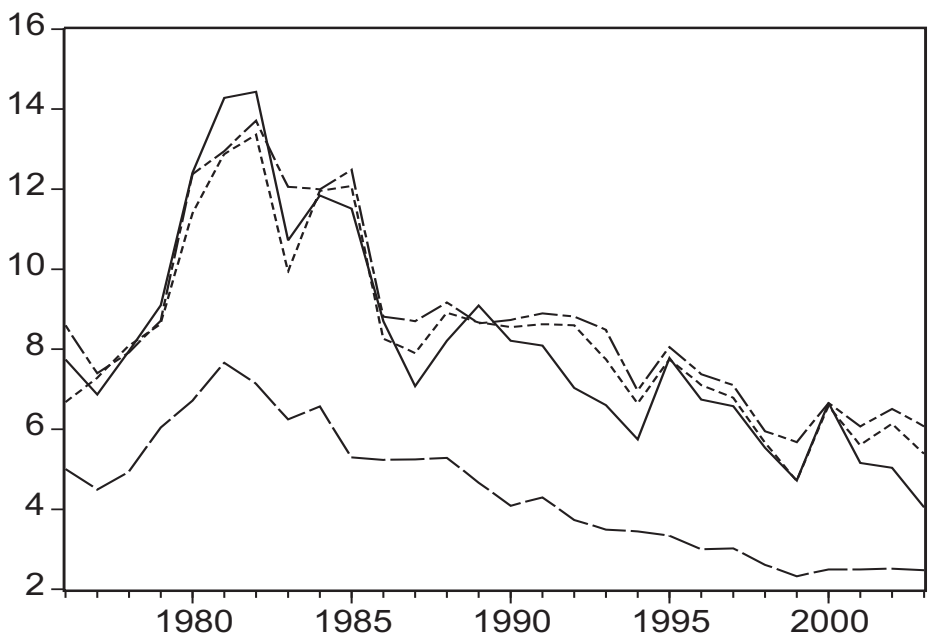

10-Year Treasury Yield ----. 5-Year-Ahead 10-Year Yield 5-Year-Ahead 5-Year Yield - - Expected Inflation

Figure 4: Projected GDP Growth and Equity Premium

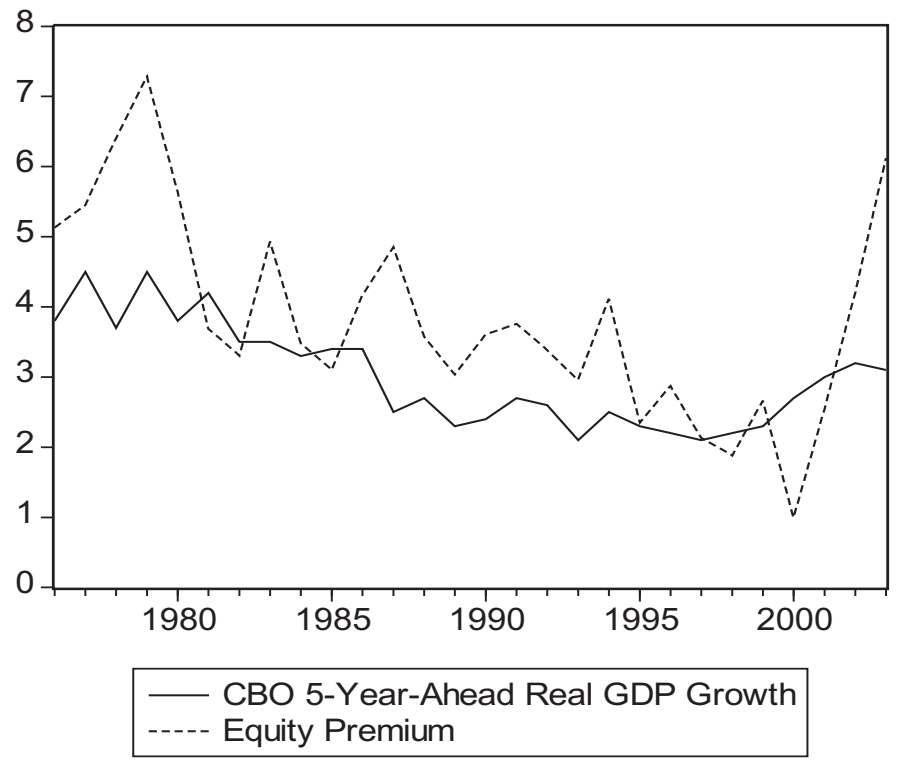

